\title{
Explicit and implicit vocabulary learning: A comparative study based on EFL textbooks in Mainland China and Hong Kong
}

\author{
Xin Liu
}

Shenzhen Foreign Languages School, Shenzhen, Guangdong Province, China

Received: October 25, 2021 / Accepted: November 2, 2021 / Published Online: November 5, 2021

(c) Pioneer Publications LTD 2021

\begin{abstract}
Purpose The purpose of this study is to evaluate the vocabulary settings in two English textbooks used in Mainland China and Hong Kong respectively, and provide useful suggestions for teachers to choose or adapt English as a foreign language (EFL) textbook. The study centers on two English textbooks for grade-nine/ JS3 EFL learners in Mainland China and Hong Kong. Methods The two textbooks will firstly be compared and contrasted at the macrolevel, covering perspectives such as organization, visual aids, glossary, and supplementary materials. Next, to study the treatment of vocabulary further at the micro-level, the study will focus on one unit in the two selected textbooks sharing the same theme. Results At the macro-level, the two textbooks are both clear and colored printed, themebased, glossary included, visual aids provided, and practice given. They mainly differ in module components and word load in the glossary. At the micro-level, both of them give pre-teaching of new words before reading/listening, present words in context, provide scaffolding, follow a sequence of difficulty, integrate well with the development of other language skills, but they are different in some ways. Conclusion In terms of vocabulary treatment, results showed that both textbooks generally follow similar organization and presentation but differ in suggested teaching approaches. The textbook used in Mainland addresses the word meaning while the textbook in Hong Kong follows a more implicit approach. In order to facilitate the evaluation of the vocabulary section in EFL textbooks, a new checklist and teaching implications for teachers are proposed in the thesis.
\end{abstract}

Keywords textbook evaluation; vocabulary settings; explicit learning; implicit learning

\section{Introduction}

Textbook is considered as an essential component to EFL or English as a second language (ESL) classroom (McGrath, 2002; Richards, 2001; Sheldon, 1988). In non-native English-speaking countries, local English teachers have a strong reliance on textbooks because of the lack of confidence and inadequate language proficiency (Reynolds, 1974). A study of 149 Hong Kong local secondary school English teachers showed that local teachers thought textbooks were one primary source of teaching materials (Richards, Tung \& Ng, 1992).

Given the above situation, evaluation of textbooks is a necessary and effective method to guarantee the contribution of textbooks to EFL teaching and learning. However, most studies and research focused on textbooks evaluation from general perspectives (Henriques, 2009; Law, 1995; Liu, 2005; Ning \& Pan, 2014), and few concerned the vocabulary sections (Cheung, 2005;

Chow, 2007). Even fewer studies compared the treatment of vocabulary in textbooks in different places. There are some comparative studies on English textbooks in Mainland China and Hong Kong, but only a few of them are related to the treatment of vocabulary. Deng (2016) made a comparative study of the textbooks used in Mainland China and Hong Kong, but the particular focus was the implementation of Task-based Language Teaching instead of vocabulary.

Based on the research gap explained above, a comparative study on the treatment of vocabulary in textbooks used in Mainland China and Hong Kong is necessary. The goal of the study is to find out the similarities and differences in the treatment of vocabulary in two textbooks. Hopefully, the findings may provide insights into vocabulary settings in English textbooks and EFL vocabulary teaching.

\section{Literature Review}




\subsection{The importance of vocabulary}

Vocabulary is fundamental to language learning, and its importance has been proved by many researchers (Carter \& McCarthy, 2014; Coady \& Huckin, 1997; DeCarrico, 2001; Nation, 2003). DeCarrico (2001, p. 258), for instance, noted that 'vocabulary learning is central to language acquisition, whether the language is first, second, or foreign.' However, the importance of vocabulary in ELF learning and the relevant research just started gaining more attention since 30 years ago because of the development of linguistics. Since the focus of language learning shifted from language rules to communication abilities (DeCarrico, 2001), vocabulary became more important in EFL learning. According to Coady and Huckin (1997), vocabulary specialists generally agree that lexical competence affects communicative competence greatly.

One central issue related to this paper is whether explicit or implicit learning is more effective in vocabulary teaching. Explicit learning is related to the learner's conscious and deliberate attempt to master some material or solve a problem (Dörnyei, 2009). It involves memorizing a series of successive facts and thus demands heavily on working memory. Sökmen (1997) introduced several key principles of explicit learning: build a large recognition vocabulary, provide many encounters with a word, promote deep-level processing, offer facilitating imaging, and encourage independent learning. He found that promoting word association and a deep level of processing are two effective techniques in vocabulary teaching. In contrast, implicit learning refers to acquiring skills and knowledge without conscious awareness (Dörnyei, 2009). In other words, it is a kind of incidental learning that encourages recognizing the meaning of words in context and giving more exposure to L2 input, especially through intensive reading and listening, and communicative practice. Implicit instruction suggests that tasks should be designed to help learners elicit linguistic forms on their own instead of having the teacher give instruction to learners directly.

There is no absolute agreement on which approach is more effective in vocabulary learning among past studies, and the mere use of either approach seems insufficient. Moreover, DeCarrico (2001) noted that explicit learning is more effective at the initial stage of EFL learning when learners need to acquire high-frequency words while the implicit approach works better in learning low-frequency vocabulary at a relatively intermediate or advanced level. Therefore, the real challenge is how to combine explicit and implicit approaches to meet learners' needs.

\subsection{Vocabulary learning strategies}

In order to find effective ways of teaching vocabulary, researchers (Ahmed, 1989; Gu \& Johnson,1996; Oxford, 1990; Schmitt, 1997) studied vocabulary learning strategies and proposed different models. Ahmed (1989) divided all strategies into two types: macro- strategies including memorization, practice, note-taking, and using different information sources, and micro-strategies regarding specific behaviors within one of the macro-strategies. On the other hand, Schmitt (1997) looked at the process of vocabulary learning and divided strategies into two categories: strategies for the discovery of a new word's meaning and strategies for consolidating a word once it has been discovered. The model proposed by Ahmed (1989) grouped strategies in a more holistic way, while Schmitt (1997) excluded some factors important to EFL learning, such as word load and the integration of vocabulary into other language skills. Therefore, Ahmed's model (1989) is more applicable to this study. In addition, understanding of word parts, using a dictionary, and guessing meaning from context are the three main vocabulary learning strategies suggested in the literature (Gairns \& Redman, 1986; Schmitt, 1997; Ur, 1996).

\subsection{Textbook evaluation}

Although there has been a debate about the necessity of textbooks in EFL learning and teaching (O'Neill, 1982; Tomlinson, 2008; Tomlinson, 2010), it is very common that ELT professionals use textbooks as a crucial component in EFL classrooms (Byrd, 2001; Cunningsworth 1984; Harmer, 1991; McDonough \& Shaw, 1993). Therefore, teachers and syllabus developers need to evaluate textbooks carefully to choose the most appropriate materials for the intended audience.

A number of researchers attempted to propose textbook evaluation frameworks (Celce-Murcia, 1979; Cunningsworth, 1984; McDonough and Shaw, 1993; Rubdy, 2003; Ur, 1996), and each framework or checklist has its own distinct features which overlap in some ways. Daoud \& Celce-Murcia (1979) developed a textbook evaluation checklist with one part for the textbook and the other for the teacher's manual. The authors divided the textbook evaluation checklist into five parts: subject matter, vocabulary and structures, exercises, illustrations, and physical make-up. It was the first time that the term 'physical make-up' had been used to refer to factors related to the 'appearance' of textbooks. Other researchers named them "technical factors" (Williams, 1983) and 'practical considerations' (McGrath, 2002). Unlike many scholars at that time, Daoud \& Celce-Murcia (1979) specified a section for vocabulary and structures to be rated and three out of nine items were directly related to vocabulary: reasonability of the load of new words introduced in every lesson, repetition of the new vocabulary in subsequent lessons, and systematic gradation from simple to complex. These three criteria are adopted in this study.

Some evaluation items can be drawn from the 19 criteria for textbook assessment suggested by Ur (1996, p. 186) with regard to objectives, approach, layout, visuals, topics and tasks, instructions, syllabus, content organization and grading, review and test, authentic language, pronunciation, vocabulary, grammar, fluency practice, independent learning strategies, guidance for the teacher, audio cassettes, and local availability. The criteria related to the review, test, and independent 
learning strategies provided more angles to evaluate the treatment of vocabulary.

Different from the above researchers, Rubdy (2003) focused on the validity of the materials, and incorporated the psychological and pedagogical issues into his framework. The researcher noted that the psychological issues (learner needs, independence and autonomy, self-development, creativity, and cooperation) of textbooks and materials affect the vocabulary learning and teaching. Furthermore, the model reflected the change of view that learning is student-centered, and their needs, wants, and long-term goals should be attended to.

Besides the above-mentioned criteria, the model of McDonough and Shaw (1993) is the main source of reference and justification for the framework of evaluation in this study. The evaluation model involves two steps: external evaluation and internal evaluation. The external evaluation is conducted first to attain a picture of organizational principles, which can be found from the cover, introduction, and table of contents. Through external evaluation, teachers can gain information concerning the intended users, the aim, the context, materials organization, the vocabulary to study, the skills to be covered, and the author's view on language teaching. In addition, factors such as availability to users and vocabulary index are also considered at the external stage.

On the other hand, the internal evaluation is conducted to look at deeper information of each unit or the components of the textbooks. Table 1 shows some of the internal factors and possible questions related to each factor.

Table 1. Criteria in the internal textbook evaluation

\begin{tabular}{|c|c|}
\hline \multirow{3}{*}{$\begin{array}{l}\text { Internal factors } \\
\text { Presentation of mate- } \\
\text { rials }\end{array}$} & Questions \\
\hline & $\begin{array}{l}\text { Are all language skills cov- } \\
\text { ered? }\end{array}$ \\
\hline & $\begin{array}{l}\text { Are the skills integrated } \\
\text { well? }\end{array}$ \\
\hline $\begin{array}{l}\text { Sequencing of mate- } \\
\text { rials }\end{array}$ & $\begin{array}{l}\text { Is there a progression of dif- } \\
\text { ficulty? }\end{array}$ \\
\hline Reading section & $\begin{array}{l}\text { Is there too much emphasis } \\
\text { on skills development of } \\
\text { reading? }\end{array}$ \\
\hline Listening section & $\begin{array}{l}\text { Are the listening recordings } \\
\text { authentic? }\end{array}$ \\
\hline Speaking section & $\begin{array}{l}\text { Does the speaking incorpo- } \\
\text { rate real interaction in life? }\end{array}$ \\
\hline $\begin{array}{l}\text { Appropriacy of tests } \\
\text { and exercises }\end{array}$ & $\begin{array}{l}\text { Is what tested or practiced } \\
\text { taught in the textbook? }\end{array}$ \\
\hline Self-study provisions & $\begin{array}{l}\text { Is it suitable for developing } \\
\text { independent learning? }\end{array}$ \\
\hline $\begin{array}{l}\text { Teacher-learner bal- } \\
\text { ance of motivation }\end{array}$ & $\begin{array}{l}\text { Can the materials motivate } \\
\text { both teachers and learners } \\
\text { alike? }\end{array}$ \\
\hline
\end{tabular}

Source: McDonough and Shaw (1993)

Many textbook evaluation models involve vocabulary but are not particularly designed for the treatment of vocabulary. Instead of listing all the criteria separately, the framework by McDonough and Shaw (1993) can cover those criteria in a comprehensive way. Therefore, the study would be conducted at two levels.

The comments on checking items in Chapter 4 have two forms drawn from the checklist by Cunningsworth (1984). In his checklist, some questions need to be answered with yes/no, while some require an evaluative comment. This is because some checking items need affirmative answers while some criteria should better be commented descriptively. For instance, questions like "is there pre-teaching of vocabulary in the textbook" can be answered simply with yes/no but questions like "what is the suggested teaching approach" need a descriptive reply.

\subsection{Textbook evaluation in Mainland and HK}

English education in Mainland and HK shares many features such as students' needs and sociolinguistic contexts but also differs in some aspects. If studied properly, both places can learn from each other and improve vocabulary teaching with textbooks. Textbook evaluation in Mainland mainly focuses on the comparison of different series of textbooks (Chen, 2015; Guo, 2012) and the fitness of textbooks to New National Curriculum (Ning \& Pan, 2004). There are very few studies on the vocabulary section in EFL textbooks, let alone comparative study of a particular perspective. Some studies focus on the vocabulary in Hong Kong textbooks (Cheung, 2005; Chow, 2007; Or, 2010), but only a few are comparative studies of textbooks in Mainland and HK. For instance, Cheung (2005) compared the treatment of vocabulary in three series of textbooks used in Hong Kong secondary schools and found a gap between what the textbooks actually offer and what needs to be included to develop vocabulary learning strategies. Deng (2016) compared the English textbooks in two areas, but the focus was not on the treatment of vocabulary in textbooks. Therefore, it is necessary to compare the English textbooks in two places to draw lessons from each other and facilitate EFL vocabulary education.

\section{Materials and Methodology}

\subsection{Research questions}

As there is a lack of comparative study on the treatment of vocabulary in the EFL textbooks used in Mainland China and Hong Kong, the paper would answer the research questions below:

1. What are the similarities and differences in the treatment of vocabulary at the macro-level between the two selected textbooks?

2. What are the similarities and differences in the treatment of vocabulary at the micro-level between the two selected textbooks?

\subsection{Selected textbooks}

The textbooks chosen are popular for grade-nine/ JS3 EFL learners in Mainland China and HK respectively. Textbook A is from an English textbook series 
published by Foreign Language Teaching and Research Press (Chen, Lu, Greenall \& Zhang, 2013), and it has been adopted in many provinces in Mainland for decades. Textbook B is from the Longman Activate Series (Harfitt, Potter, Rigby \& Wong, 2012) published by Pearson Education Asia Limited, which is used commonly in HK local government schools.

The two series of textbooks are selected for four reasons: (1) Both series enjoy high popularity in respective areas and are widely used in textbook studies (Chen, 2015; Guo, 2012; Qiu \& Lu, 2014); (2) Both series have been used as EFL textbooks for at least 15 years, and the updated versions are published in last five years; (3) Both series are developed and edited by professionals (educators, editors, and English-native speakers); and (4) Both textbooks face intended audience of similar age and contain one module sharing the same theme (environmental issues), which can minimize the variables in comparison of vocabulary settings brought by topic differences.

The basic information of the two textbooks is presented in Table 2.

Table 2: Basic information of selected textbooks

\begin{tabular}{|c|c|c|}
\hline Perspectives & Textbook A (Mainland) & Textbook B (HK) \\
\hline Intended audience & Ninth-graders: $15-16$ years old & Junior-secondary Year 3: 15-16 years old \\
\hline Proficiency level & $1300-1400$ words; $200-300$ collocations & 2500-3000 words \\
\hline Context & $\begin{array}{l}\text { English is a core course. } \\
\text { English is a foreign language. }\end{array}$ & $\begin{array}{l}\text { English is commonly used in life and work. } \\
\text { English is between EFL and ESL. }\end{array}$ \\
\hline Organization & $\begin{array}{l}\text { Each of the } 12 \text { modules is grouped into three } \\
\text { units, including two review modules. }\end{array}$ & $\begin{array}{l}\text { Each of the four modules contains eight } \\
\text { sections. }\end{array}$ \\
\hline Aim & $\begin{array}{l}\text { Positive attitude and strong interest in Eng- } \\
\text { lish learning, language knowledge and skills, } \\
\text { English learning strategies, understanding of } \\
\text { world culture, and awareness of culture ex- } \\
\text { change. }\end{array}$ & $\begin{array}{l}\text { To reach the learning targets and objectives } \\
\text { for Key Stage } 3 \text { outlined in the } 1999 \text { Eng- } \\
\text { lish Language Syllabus for Secondary 1-5. }\end{array}$ \\
\hline $\begin{array}{l}\text { Suggested teaching } \\
\text { approaches }\end{array}$ & Centered on the practical needs of learners & Theme-based and task-based approach \\
\hline
\end{tabular}

It should be noted that both textbooks did not give information on proficiency level, so the proficiency levels are assumed based on the documents published by the national education organizations. According to the National English Curriculum (2011), learners are supposed to be able to use 1,500-1,600 words and 200300 collocations well by the end of grade nine. Thus, it is assumed that the proficiency level of the intended audience is $1,300-1,400$ words. Although there is no exact requirement on target vocabulary for each key stage in Hong Kong official documents, a project led by the Education and Manpower Bureau (EMB) and CUHK (headed by Arthur McNeill) to develop an English vocabulary curriculum for 12 years of compulsory education in Hong Kong indicates that the 'stage target' for KS3 (Secondary 1-3) is 1,500 words and the 'cumulative target' is 3,500 words. It is estimated that the average vocabulary size of the target students is around 2,500-3,000 before they enter Year 3. The intended audience's language proficiency in textbook $\mathrm{B}$ is higher than that in textbook A.

\subsection{Method}

The two textbooks will firstly be compared and contrasted at the macro-level, covering perspectives such as organization, visual aids, glossary and supplementary materials with reference to literature reviewed in Chapter 2. Next, the study will be narrowed down to one unit in the two selected textbooks sharing the same theme (Module 12 in textbook A and Module 7 in textbook B) to find out similarities and differences regarding the treatment of vocabulary.

\section{Findings and Discussion}

\subsection{Macro-level evaluation}

Although many textbooks are of good quality in cover and print nowadays, such factors are still worth considering when evaluating a textbook because they do affect the overall learning experience. Many researchers (Rubdy, 2003; Ur, 1996) suggest that physical factors such as cover, layout, and print should be attractive to the intended audience. Since both textbooks are colored and clear printed, they can be compared critically in this study.

The macro-level study was conducted to attain an overview of the vocabulary treatment in the textbooks ranging from physical factors such as organization, visual aids, and glossary to supplementary materials. Table 3 presents the components of one module in each textbook. 
Table 3: The external information of the two textbooks

\begin{tabular}{|c|c|c|c|}
\hline Textbook A & Details & Textbook B & Details \\
\hline Unit 1 & $\begin{array}{l}\text { Listening and vocabulary; pronuncia- } \\
\text { tion and speaking }\end{array}$ & Opening page & $\begin{array}{l}\text { A summary of the target vocabulary, } \\
\text { grammar, and skills featured }\end{array}$ \\
\hline Unit 2 & Reading and vocabulary; writing & Warm-up & $\begin{array}{l}\text { A pre-reading activity or vocabulary } \\
\text { building skill segment }\end{array}$ \\
\hline Unit 3 & $\begin{array}{l}\text { Language in use; language practices; } \\
\text { around the world; module task }\end{array}$ & $\begin{array}{l}\text { Reading and lis- } \\
\text { tening }\end{array}$ & $\begin{array}{l}\text { At least one language arts text and one } \\
\text { listening text }\end{array}$ \\
\hline \multirow[t]{7}{*}{ Appendices } & $\begin{array}{l}\text { Language notes; guide to language } \\
\text { use; words and expressions; proper }\end{array}$ & Comprehension & $\begin{array}{l}\text { Practice of reading skills and listening } \\
\text { skills }\end{array}$ \\
\hline & $\begin{array}{l}\text { name; a list of vocabulary in alpha- } \\
\text { betic order; a table of irregular verbs }\end{array}$ & Vocabulary & $\begin{array}{l}\text { Vocabulary from at least two key lexi- } \\
\text { cal groups; practice of new words and } \\
\text { phrases }\end{array}$ \\
\hline & & Grammar & $\begin{array}{l}\text { Two or three core grammar items; a } \\
\text { speaking skills box }\end{array}$ \\
\hline & & Integrated task & $\begin{array}{l}\text { Use the vocabulary and grammar pre- } \\
\text { sented; a writing skills box }\end{array}$ \\
\hline & & Self-assessment & $\begin{array}{l}\text { Assessment of vocabulary and gram- } \\
\text { mar }\end{array}$ \\
\hline & & Extension task & $\begin{array}{l}\text { Every two modules to provide expo- } \\
\text { sure to one of the eight senior second- } \\
\text { ary elective modules }\end{array}$ \\
\hline & & Appendices & $\begin{array}{l}\text { A glossary; a table of language fea- } \\
\text { tures; a table of verb forms; a list of ir- } \\
\text { regular verbs; a table of personal pro- } \\
\text { nouns and possessives; grammar refer- } \\
\text { ences }\end{array}$ \\
\hline
\end{tabular}

Textbook A (Mainland) and textbook B (Hong Kong) are compared as follows.

\subsubsection{Organization}

A clear and reasonable organization is very important to the effectiveness of textbook since teachers usually refer to the organization of textbooks to design their syllabus and plan lessons, and learners use textbook as a major tool in preview and review. It is suggested by Nunan (1991) that sensible grouping and organization of words can facilitate vocabulary learning while fragmentation may lead to confusion. The two textbooks are theme-based, and a set of units sharing the same theme are grouped as a module. At the modular level, each unit is composed based on the target language skills in both textbooks with some differences in organization. There is an opening page at the beginning of one module to give an overview of learning objectives in textbook B, while there is no such part in textbook A. However, the information can be attained from the table of scope and sequence, so the difference can be negligible. Also, there is one warm-up section in textbook B to engage users in learning but there is no such section in textbook A. Moreover, there is a unit of vocabulary only in textbook $\mathrm{B}$, between the comprehension and grammar unit, to consolidate the words that appeared before and provide extra words related to the theme. It shows that vocabulary is regarded as important as other language skills in textbook $\mathrm{B}$, but in textbook A, vocabulary is the facilitator of language skill development.

The importance of repetition and review in vocabulary learning has been acknowledged by researchers
(Nation, 1994; Sökmen, 1997). Nation (1990) suggested that students cannot develop strong memory of the words without sufficient encounters and revisions. Therefore, students should have adequate chances to meet and use the words they have learned earlier. Ur (1996) also included "periodical review and test sections" as a criterion in textbook evaluation. There is an independent unit for practicing and testing the target vocabulary in both textbooks but named differently. It is called 'language in use' in textbook A and called 'self-assessment' in textbook B. It is found that textbook A devotes more space for practices than textbook $\mathrm{B}$, which implies that the authors of textbook A attach more importance to intensive practices.

In terms of revision, textbook $\mathrm{A}$ has a revision module regarding all language skills and vocabulary, while textbook B doesn't. It is fixed that each book only provides two revision modules regardless of how many modules are included in one textbook. In the series of textbooks used in Mainland, the textbook for the $1^{\text {st }}$ term contains 12 modules while the book for the $2^{\text {nd }}$ term has eight modules, but the revision section's frequency is twice a term. The findings of the organization show that textbook A devotes more importance to practice and review while textbook B stresses activating learner's interest and motivation.

\subsubsection{Visual aids}

Both textbooks provide visual aids to facilitate vocabulary learning, but textbook B gives more visual aids than textbook A. It is found that textbook B uses more pictures than textbook $\mathrm{A}$ in the practice section. The importance of visual aids is proposed by researchers such as Gairn \& Redman (1986) and Ur (1996). As 
visual aids can support vocabulary learning effectively, Ur (1996) set "appropriate visual materials available" as one criterion in her checklist.

\subsubsection{Glossary}

While glossaries have not always been found to make a significant contribution to comprehension, they generally have a positive effect on vocabulary learning (Nation, 2003). The two textbooks' glossaries present the information regarding the part of speech, the page number or line number as the word appears in the text, the pronunciation, and Chinese meaning. Both glossaries include words that show in reading texts only and the words are organized in the order of module. However, the word load is very different. Textbook A provides 336 words in the glossary, which is much more than the 70 words provided in textbook B. That, however, does not imply the target vocabulary in textbook B is less than that in textbook A. Instead, the data suggest that the density of the new words in the reading tasks in textbook $\mathrm{A}$ is higher than that in textbook B.

\subsubsection{Supplementary materials}

Supplementary materials refer to workbooks, test papers, and audio or visual materials provided besides the textbook. Regarding the vocabulary, only textbook $\mathrm{B}$ has a workbook for vocabulary and structures to help learners reinforce new knowledge. The provision of a workbook may affect the settings related to vocabulary such as the amount of exercise in textbooks. Yet, given that this paper's focus is textbook, the further information of workbook is not concerned.

The findings of the macro-level comparison are summarized in Table 4 below with Yes/No comments. 'Yes' implies the textbook meets the criterion, and 'No' refers to the inadequacy in such perspectives.

Table 4: Findings of the macro-level evaluation

\begin{tabular}{lcc}
\hline \multicolumn{1}{c}{ Criteria } & Textbook A & Textbook B \\
\hline Physical make-up & Yes & Yes \\
Organizing & Yes & Yes \\
Opening pages & No & Yes \\
Warm-up & No & Yes \\
Vocabulary unit & No & Yes \\
Glossary & Yes & Yes \\
Visual aids & Yes & Yes \\
Supplementary ma- & No & Yes \\
terials & & \\
Practice and test & Yes & Yes \\
Regular revision & Yes & No \\
\hline
\end{tabular}

\subsection{Micro-level evaluation}

In this part, the study would be focused on one specific module from two textbooks to look for more similarities and differences. Module 12 (Save our world) in textbook A and Module 7 (Our beautiful planet) in textbook B are both organized around the theme of environmental issues, and they are compared in the following aspects.

\subsubsection{Suggested teaching approaches}

As it is found in the macro-level evaluation, there is no opening page and warm-up for each module in textbook A. In addition, it is the routine that there is a pre-teaching section of key vocabulary that learners would encounter in reading and listening tasks at the beginning of the unit (see Figure 1). In contrast, textbook B provides an opening page and warm-up unit to stimulate students' interest and spark thinking before learning. There is also pre-teaching of vocabulary before reading, but it is not always about the meaning of new words. In Module 7 of textbook B, the pre-reading part aims at vocabulary building skills instead of teaching the meaning of new words (see Figure 2). It is noted that textbook A introduces the vocabulary building skills in the unit of 'language in use' as supplementary knowledge, but textbook B regards such skills as helpful in learning new words.

Look at the title of the passage. What suggestions do you think the passage will make? Use the words in the box to help you.

$$
\text { china divide necessary plastic policy reuse }
$$

\section{Figure 1}
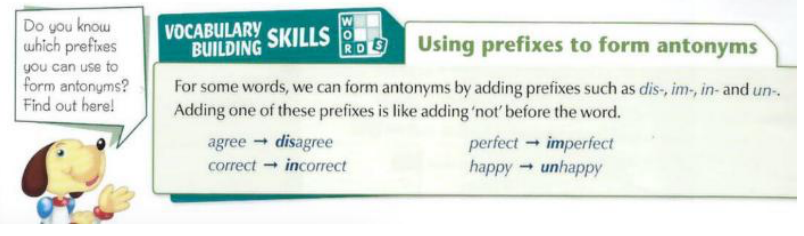

Figure 2

Therefore, both textbooks follow the process of pre-teaching, retention, practice, and review in vocabulary learning, but textbook A follows the rule firmly, and learners are supposed to learn words explicitly by finishing the tasks with the new words given in prereading. In contrast, textbook $\mathrm{B}$ does not give much emphasis on pre-teaching the new words for reading or listening. Such distinction implies that the suggested teaching approaches are different. Textbook A suggests the meaning of new words should be taught deliberately, while textbook B prefers promoting incidental learning and recognizing the meaning of words in context. Both approaches have their advantages and disadvantages. The teaching approach in textbook A guarantees the chance for the acquisition of information by direct attention to it (Khamesipour, 2015), but may cause a burden on working memory. The implicit approach in textbook B provides multiple exposure to new words in different contexts, which improves the quality of knowledge and consolidates the words in memory (Schmitt, 2008). However, research shows that incidental learning from reading takes longer than explicit learning to master the same amount of knowledge (Horst, 2005). In other word, the implicit approach may not be as effective as explicit instruction in vocabulary teaching, especially for true beginners of English.

\subsubsection{Presentation}

Researchers (Krashen, 1989; Oxford \& Crookall, 1990) advocate learning words in contexts as learners can consolidate their memory of old knowledge and use 
clues to infer the meaning of new words. Both textbooks present words in context at the input stage, and textbook B provides more texts of various topics and genres than textbook A. For example, before the unit of practice, students read two passages in textbook $\mathrm{A}$, but in textbook $\mathrm{B}$, learners read three texts. The reading texts in textbook A are a dialogue and an exposition, while textbook B involves poems, speeches, text on webpages, and newspaper reports.

\subsubsection{Grading}

Language is a system that follows the grading principle of less to more and simple to complex. The contents of textbooks should also be sequenced reasonably. In textbook B, every two modules serve as one general topic. For example, Module 7 (Our beautiful planet) and Module 8 (The world of the future) are under the topic 'my challenges', and the previous topic is 'my leisure.' It can be found that textbook B follows a sequence of personal-to-world and simple-to-complicated. However, the criteria for arranging the 12 modules in textbook A are not obvious. In fact, Module 10 whose theme is countries and nationalities could be interchanged with Module 11 whose theme is school life. Therefore, the contents don't fit and go with each other in textbook A, and thus the sequencing needs improvement.

\subsubsection{Scaffolding}

There are hints or notes that explain the meaning of rare words and provide ways to complete the tasks in both textbooks, which facilitates students' vocabulary learning. For example, in textbook B (page 60), the students need to read a poem reflecting the influences of climate change on animals' life. A note (Figure 3 ) about 'doe' is given at the margin of the page to clear the possible confusion. Both textbooks provide support or scaffolding (Bruner, 1978) for vocabulary learning, but textbook B provides more.

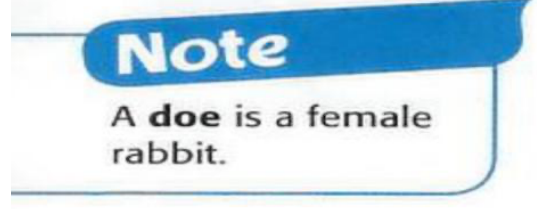

\subsubsection{Integration}

The vocabulary is integrated with the development of other language skills in both textbooks, which helps learners to attain the learning objectives. Integration is one criterion also set by Cunningsworth (1995) in his checklist of textbook evaluation. Take textbook A as an example, the words in pre-teaching are common in later listening tasks to develop the listening skills (listening and identifying views).

\subsubsection{Practice and review}

Both textbooks provide practice of vocabulary taught and only test already taught words. Thus, there is 'an appropriacy between exercises and teaching' (McDonough \& Shaw, 1993). As for the form of practice, textbook B gives vocabulary exercises in many forms such as 'crossword puzzles' and 'circling the most appropriate words.' Nevertheless, 'fill-in blanks with words given' is almost the only exercise in textbook A. According to Nation (1994), repetition leads to boredom, so textbook A should enrich the forms of practices.

At the end of each module, there is a review of the ought-to-be mastered vocabulary in both textbooks. The main difference lies in the influences on students' learning strategies. In textbook $\mathrm{A}$, students can finish the review either independently or with the help of teachers. It does not mention the purpose or use of the review, which makes it nothing different from the exercises in other sections. In contrast, textbook $\mathrm{B}$ does the review as a self-assessment, asking the learner to reflect on how much they have learned in this module by filling in a self-assessment form first. Then they check their own judgments by doing the tasks. Also, the instructions are friendly and student-centered by using second-person sentences. The self-assessment unit in textbook B is helpful to develop the awareness of selfstudy and motivate learners to review regularly. Cunningsworth (1995) advocated 'emphasis placed on strategies for individual learning' because with the proficiency improving, learners would come across more low-frequency words and the demand for individual learning strategies is growing as well. The findings of comparison at the micro-level are presented in the table 5 below.

Figure 3

Table 5: micro-level comparison of two textbooks

\begin{tabular}{|c|c|c|c|}
\hline Criteria & Textbook A & Textbook B & Remarks \\
\hline $\begin{array}{l}\text { Suggested teach- } \\
\text { ing approaches }\end{array}$ & $\begin{array}{l}\text { Pre-teaching-reten- } \\
\text { tion-practice-review }\end{array}$ & $\begin{array}{l}\text { Pre-teaching-retention- } \\
\text { practice-review }\end{array}$ & $\mathrm{A}$ is more explicit \\
\hline $\begin{array}{l}\text { Word-building } \\
\text { skills }\end{array}$ & Yes & Yes & $\begin{array}{l}\mathrm{A} \text { in the unit of practice } \\
\mathrm{B} \text { in pre-reading }\end{array}$ \\
\hline Presentation & Contextualized & Contextualized & $\mathrm{B}$ provides more texts \\
\hline Scaffolding & Yes & Yes & \\
\hline Grading & No & Yes & $\begin{array}{l}\text { Glossary does not follow the sequence of dif- } \\
\text { ficulty in both textbooks }\end{array}$ \\
\hline Integration & Yes & Yes & \\
\hline Practice & Few forms & Various forms & Appropriacy between exercises and teaching; \\
\hline Review & Yes & Yes & B motivates self-study more \\
\hline
\end{tabular}




\section{Conclusions}

\subsection{Summary of the major findings of the study}

The two textbooks share many similarities. At the macro-level, they are both clear and colored printed, theme-based, glossary included, visual aids provided, and practice given. They mainly differ in module components and word load in the glossary. At the microlevel, both of them give pre-teaching of new words before reading/listening, present words in context, provide scaffolding, follow a sequence of difficulty, integrate well with the development of other language skills, but they are different in some ways. It is found that Textbook A follows a more explicit approach, addressing the word meaning and the form of vocabulary practice is monotonous. Textbook B focuses more on the meaning of contents and prefers to provide learners with more texts to acquire new words and encourage learners to develop learning skills such as self-study.

\subsection{Pedagogical implications}

The study provides some pedagogical implications for teachers about the selection of textbooks and vocabulary teaching. First, teachers need to evaluate the treatment of vocabulary critically to choose the most appropriate materials for students. Second, there should be a proper combination of implicit and explicit learning in vocabulary teaching. Third, a new checklist for vocabulary section in EFL textbooks is suggested based on the assessment done above and relevant literature (Byrd, 2001; DeCarrico, 2001; Rubdy, 2003; McDonough \& Shaw, 1993; Ur, 1996; Zabawa, 2001). Researchers put the checking items regarding vocabulary in different ways since they have a different emphasis. Some put the checking items in a single section (Williams, 1983), some make them together with grammar (Celce-Murcia, 1979), and some scatter them in different sections (Rubdy, 2003). Here the checking items are categorized in the sequence of vocabulary learning: pre-learning, while-learning and, after-learning because sometimes it is hard to distinguish the macro-level and micro-level evaluation completely and the process model is applicable to most vocabulary teaching classrooms. For example, the way a textbook organizes materials is of the macro-level, but how is each task or material sequenced is related to the microlevel.

In pre-learning, teachers can evaluate the vocabulary settings with reference to two questions: Is there an introduction to the target vocabulary first? Is the vocabulary load reasonable for target students? In the section on while-learning, the following questions can provide teachers with evaluation standards:

a. Is there scaffolding / hint through the learning process?

b. Does the vocabulary help them to attain any of their learning goals? c. Is the vocabulary integrated with other language skills or tasks?

d. Is the vocabulary contextualized?

e. Is there a progression of difficulty in vocabulary?

f. Is there a part featuring word building skills?

g. Are the vocabulary tasks in various forms?

h. Does the textbook contain visual aids for vocabulary learning?

As for the part of after-learning, teachers can refer to the questions below to make a proper judgment on the vocabulary treatment in textbooks: Are there supplementary materials for vocabulary learning? Is a glossary included in the coursebook? Is there a regular revision of vocabulary from previous classes? Is what tested or practiced taught in the coursebook?

Teachers can use the checklist suggested to evaluate the vocabulary treatment in textbooks but should not confine to the suggested criteria. It is suggested that teachers should adopt the framework and incorporate it with their own teaching context.

The study shows that teachers should have a clear understanding of the textbook they are using or going to use so that they can provide the best vocabulary learning materials appropriate for their students. For users of textbook A, more work should be done on the flexibility of the teaching approach and how to maintain learners' interest and motivation. Textbook B users should not ignore teaching the meaning of words while guaranteeing enough exposure to L2. Both textbooks should consider more on developing the vocabulary learning strategies and expanding vocabulary learning outside of class.

\subsection{Limitations of the study and future research}

There are some limitations to clarify in this study. First, the research scope is relatively small because it only compares one textbook of each series and only one module of each textbook. It is suggested by McDonough \& Shaw (1993) that at least two modules are necessary to gain a clear and comprehensive understanding of the textbook at the internal stage. Second, although justifications are provided when designing the new checklist, it lacks actual practices to verify the reliability and validity. Third, as stated in Chapter 2, the target students' language proficiency in the two textbooks is different, which may affect the treatment of vocabulary to some extent. This is a variable that cannot be eliminated in this study.

In future research, more studies on the vocabulary treatment of textbooks of different levels are needed to find more details across the whole series. Also, a wide range of supplement materials can be studied in the future because textbook is not the only material that affects vocabulary learning. Since more and more publishers provide multi-media materials and online resources to facilitate learning, the use and influence of such new-form supplementary materials on vocabulary learning deserve further studies. 
Xin Liu is a high-school English teacher at Shenzhen Foreign Languages School in China. She holds a master's degree in Teaching English to Speakers of Other Languages from The University of Hong Kong. Her research interests are EFL teaching, methodology, learning strategies, textbook evaluation, etc.

\section{References}

Ahmed, M. O. (1989). Vocabulary learning strategies. In P. Meara (Ed.), Beyond words (pp. 3-14). London: British Association for Applied Linguistics, in association with Centre for Information on Language Teaching and Research.

Bruner, J. (1978). Learning how to do things with words. In J. Bruner \& A. Garton (Eds.), Human Growth and Development. Oxford: Oxford University Press.

Byrd, P. (2001). Textbooks: Evaluation and selection and analysis for implementation. In M. CelceMurcia, (Ed.), Teaching English as a second or foreign language (3rd ed). Boston: Heinle and Heinle.

Carter, R., \& Mccarthy, M. (2014). Vocabulary and Language Teaching. https://doi.org/10.4324/9781315835860

Charles, F. (1945). Teaching and Learning English as a Foreign Language. Ann Arbor: University of Michigan Press.

Chen, Y. Q. (2015). A comparative study based o $\mathrm{n}$ the NSEC and NSE senior English textboo ks. Overseas English.

Chen, L., Lu, Z. W., Greenall, S., \& Zhang, L. Z. (2013). English textbooks (Grade nine A). Beijing: Foreign language teaching and research Press.

Cheung, C. B. [張燦虎]. (2005). An evaluation of the treatment of vocabulary in Hong Kong secondary school English textbooks. (Thesis). University of Hong Kong, Pokfulam, Hong Kong SAR. https://doi.org/10.5353/th_b3164989

Chow, S., Jeffrey. (2007). An investigation of vocabulary coverage in English language teaching textbooks used in Hong Kong secondary schools. https://doi.org/10.5353/th_b3870665

Coady, J., \& Huckin, T. (Eds.). (1997). Second Language Vocabulary Acquisition. https://doi.org/10.1017/cbo9781139524643

Cunningsworth, A. (1984). Evaluating and selecting EFL teaching materials. London: Heinemann Educational Books.

Cunningsworth, A. (1995). Choosing your coursebook. Oxford: Heinemann.

Daoud, A. M. \& Celce-Murcia, M. (1979). Selecting and evaluating a textbook. In M. Celce-Murcia and L. McIntosh (Eds.), Teaching English as a Second or Foreign Language. New York: Newbury House.

DeCarrico, J. S. (2001). Vocabulary learning and teaching. In M. Celces-Murcia (Ed.), Teaching English as a second or foreign language (pp. 285-299). Boston: Heinle \& Heinle.
Deng, L. A. (2016). English textbooks in Hong Kong and in Chinese Mainland: a comparative analysis of new way to English and go for it in terms of TBLT [Master's Thesis, The Hong Kong Polytechnic University].

Dörnyei, Z. (2009). The Psychology of Second Language Acquisition. Oxford University Press.

Gairns, R., \& Redman, S. (1986). Working with words: a guide to teaching and learning vocabulary. Cambridge University Press.

Gu, Y., \& Johnson, R. K. (1996). Vocabulary Learning Strategies and Language Learning Outcomes. Language Learning, 46(4), 643-679. https://doi.org/10.1111/j.14671770.1996.tb01355.x

Guo, J. R. (2012). A comparison of NSEC and NSE Senior English Textbooks. Journal of Teaching and Management, 36, 87-88.

Harfitt, G., Potter, J., Rigby, S., \& Wong, K., (2012). Longman Activate Series. Hong Kong: Pearson Education Asia Limited.

Harmer, J. (1991). The Practice of English Language Teaching. Harlow, Essex: Longman.

Henriques, S. (2009). An evaluation of English as a foreign language textbooks for secondary schools in Angola [doctorate dissertation, University of Kansas]. ProQuest Dissertations and Theses Global.

Horst, M. (2005). Learning L2 Vocabulary through Extensive Reading: A Measurement Study. The Canadian Modern Language Review, 61(3), 355382. https://doi.org/10.3138/cmlr.61.3.355

Khamesipour, M. (2015). The effects of explicit and implicit instruction of vocabulary through reading on EFL learners' vocabulary development. Theory and Practice in Language Studies, 5(8), 1620-1627. https://doi.org/10.17507/tpls.0508.11

Krashen, S. (1989). We Acquire Vocabulary and Spelling by Reading: Additional Evidence for the Input Hypothesis. The Modern Language Journal, 73(4), 440-464. https://doi.org/10.1111/j.15404781.1989.tb05325.x

Law, W. G. (1995). Teachers' evaluation of English textbooks: an investigation of teachers' ideas and current practices and their implications for developing textbook evaluation criteria [Master's thesis, The University of Hong Kong]. https://doi.org/ 10.5353/th_b3195798

Liu, D. Y. (2005). On evaluation criteria of English teaching materials. Foreign Language of China, 2(6), 14-17, 23.

https://doi.org/10.13564/j.cnki.issn.16729382.2005.06.007

McDonough, J. \& Shaw, C. (1993). Materials and Methods in ELT. Oxford: Blackwell.

McGrath, I. (2002). Materials evaluation and design for language teaching. Edinburgh: Edinburgh University Press.

Nation, I. S. P. (1990). Teaching and learning vocabulary. Boston: Heinle and Heinle. 
Nation, I.S.P. (1994) Review of three books on vocabulary teaching. System, 22(2): 15-19.

Nation, I. S. P. (2003). Materials for teaching vocabulary. In B. Tomlinson(Ed.), Developing materials for language teaching. London: Continuum, (pp.394-405). https://doi.org/10.5040/9781474211826.ch-023

Ministry of Education, PRC. (2011). National English Curriculum. Beijing: People's Education Press.

Ning, J. H. \& Pan, S. X. (2014). Senior high school English textbook evaluation under the New Curriculum. Journal of Guilin normal college, 28(2).

Nunan, D. (1991). Language Teaching Methodology. New York: Prentice Hall.

O’Neill, R. (1982). Why use textbooks? ELT Journal, 36(2), 104-111. https://doi.org/10.1093/elt/36.2.104

Or, C. (2010). An investigation of the presentation and treatment of vocabulary in two secondary English textbooks in Hong Kong. https://doi.org/10.5353/th b4517642

Oxford, R. L. (1990). Language Learning Strategies: What Every Teacher Should Know. Boston: Heinle \& Heinle.

Oxford, R., \& Crookall, D. (1990). Vocabulary Learning: A Critical Analysis of Techniques. TESL Canada Journal, 7(2), 09. https://doi.org/10.18806/tesl.v7i2.566

Qiu, H. \& Lu, Q. L. (2014). Comparing English textbooks for grade seven: A case study of textbooks by foreign language teaching and research Press and People's Education Press. Survey of Education, 3(19).

Reynolds, P. D. (1974). English Language Teaching and Textbooks in Hong Kong.

Richards, J. C., Tung, P., \& Ng, P. (1992). The Culture of the English Language Teacher: A Hong Kong Example. RELC Journal, 23(1), 81-102. https://doi.org/10.1177/003368829202300106

Richards, J. C. (2001). Curriculum Development in Language Teaching. https://doi.org/10.1017/cbo9780511667220

Rubdy, R. (2003). Selection of Materials. In Tomlinson, B. (Ed.), Developing Materials for Language Teaching. https://doi.org/10.5040/9781474211826.ch-002

Schmitt, N. (1997). Vocabulary learning strategies. In N. Schmitt \& M. McCarthy (Eds.), Vocabulary: Description, acquisition and pedagogy (pp.199227). Cambridge: Cambridge University Press.

Schmitt, N. (2008). Teaching Vocabulary. Longman Teacher Guidelines Series.

Sheldon, L. E. (1988). Evaluating ELT textbooks and materials. ELT Journal, 42(4), 237-246. https://doi.org/10.1093/elt/42.4.237

Sökmen, A. (1997). Current Trends in Teaching Second Language Vocabulary. In N. Schmitt, \& M. McCarthy (Eds.), Vocabulary: Description, Acquisition and Pedagogy (pp. 237-257). Cambridge: Cambridge University Press.
Tomlinson, B. (Ed.). (2008). English Language Teaching Materials. London: Continuum. https://doi.org/ 10.5040/9781474212182

Tomlinson, B., \& Masuhara, H. (2010). Research for materials development in language learning: evidence for best practice. https://doi.org/10.5040/9781474211949

Ur, P. (1996). A course in language teaching: Practice and theory. Cambridge: Cambridge University Press.

Williams, D. (1983). Developing criteria for textbook evaluation. ELT Journal, 37(3), 251-255. https://doi.org/10.1093/elt/37.3.251

Zabawa, J. (2001). Criteria for FCE textbook evaluation: an attempt at questionnaire formulation. 